Jurnal Ekonomi \& Studi Pembangunan

Volume 19, Nomor 1, April 2018, hlm. 35-40

DOI: 10.18196/jesp.19.1.4297

\title{
EXCHANGE RATE FLUCTUATIONS AND NIGERIA'S CAPITAL ACCOUNT
}

\author{
Ibrahim Abidemi Odusanya, Adesola Bolaji Adesoye, Ayinla Idris Gbadamosi
}

Department of Economics, Olabisi Onabanjo University, P.M.B. 2002, Ago-Iwoye, Nigeria

Correspondence E-mail: ibrahim.odusanya@oouagoiwoye.edu.ng

\begin{abstract}
This paper examines the effect of exchange rate fluctuations on the capital account in $\mathrm{Ni}$ geria from 1980 to 2015. The data used for the study were retrieved from the Central Bank of Nigeria Bulletin. The study employed Johansen co-integration test, Error Correction Model (ECM) and Fully Modified Ordinary Least Square (FMOLS). Evidence from the study shows that exchange rate has no effect on the capital account. As a result of the study, production in the Nigerian economy must be encouraged through availability of domestic credit while market determined interest rate should be encouraged to stimulate economic growth and investment

Key Words: exchange rate, nominal domestic credit, balance of payments

JEL Classification: C22, F31, F32, F41
\end{abstract}

\section{INTRODUCTION}

The strong foreign exchange rate and surplus balance of payments are some of the key factors of a nation's development. They are factors essential for comparing a country's relationship with other nations. Inflation rate, foreign direct investment, external reserve, external debt, and interest rate among other variables determine the exchange rate of a country, which directly or indirectly affect the balance of payments and the $\mathrm{Ni}$ gerian economy at large. In 1973 and 1979, the exchange rate was relatively stable as due oil boom. However, Nigeria started recording huge balance of payments deficits and very low foreign reserve in the mid-80s. This was evident after the introduction of the Structural Adjustment Program (SAP), which led to continued depreciation of the naira with a view to achieve a realistic exchange rate that would facilitate improved macroeconomic performance and diversify the productive base of the economy.

Following the adoption of the Structural Adjustment Program (SAP) in 1986, the country has moved away from a pegged to a flexible ex- change rate regime. Despite the efforts of the Nigerian government to maintain a relatively stable rate of exchange, the naira has continued to depreciate before and after the introduction of the guided deregulation of 1994 when the exchange rate was 21.886 naira against the US dollar. During the global financial crisis in 2008, the exchange rate of the naira further depreciated to N150.01 at the end of 2009 (Aliyu, 2009). As at the last quarter of 2017, one US dollar exchanged for 305 naira. Nigeria's foreign trade structure did not satisfy the conditions for a successful balance of payments policy because of the over reliance on importation, low level of production and exportation of goods. Exportation of crude petroleum and agricultural produce, whose prices are predetermined in the world market with low imports and export price elasticity of demand, characterized the country's foreign structure. All of these have contributed to the worsening position of the balance of payments (BOP). Exchange rate management in Nigeria has been very poor. It has been pernicious to trade, with the country being a consistent net importer. 
The fluctuations in exchange rate do exert on the current and capital account balances (Kandil, 2009). The current and capital account deficit may be beneficial to developing countries if foreign debt complements low capital formation of the internal economy and consequently stimulates economic growth. On the other hand, empirical evidence shows that running a large and persistent current and capital account deficit may be risky and even detrimental to the economy. Given the fact that Nigeria is still fulfilling a number of loan obligations to international financial organizations, it is quite apt and imperative to examine how movements in the country's exchange rate affect the capital account component of the BOP. Thus, contrary to earlier studies, this paper specifically examines the effects of exchange rate on capital account in Nigeria. The paper is divided into five sections. Section 2 reviews relevant literature. In section 3, we present data and the methodology of the study. Section 4 contains our results while section 5 concludes the paper.

Frenkel (2004) examined aggregate employment behaviour in response to real exchange rate movements in Argentina, Brazil, Chile and Mexico between 1980 and 2003. Real exchange rate has long-run negative impact on current account component of the balance of payments. Isard (2007) found evidence that the alignments of exchange rates have a critical influence on the rate of growth of per capita output in low-income countries and the balance of payments difficulties. Obaseki (2000) and Aliyu (2007) examined Nigeria's foreign exchange management regimes as well as mechanisms of fixing the critical challenges associated with foreign exchange in the economy. Their studies equally addressed foreign exchange dynamics and established that Nigeria's external trade policies have not been significantly achieving expected macroeconomic targets. Ozturk and Acaravci (2010) used autoregressive distributed lag model to investigate the Thirlwall hypothesis for South Africa. The study found evidence in support of the Thirlwall hypothesis. Thus, equilibrium income was equal to the actual income growth. In addition, imports were cointegrated with relative prices and equilibrium growth rate. Patricia and Osi (2010) examined the balance of payments equilibrium in the West African Monetary Zone. The results of withincountry effects and the cross-country effects indicate that interest rate and growth in output play a significant role in achieving a favourable balance of payments.

Oyovwi (2012) offered empirical evidence on the impact of real exchange rate volatility on Nigeria's import and the balance of payments. The result indicated that real exchange rate volatility had no significant effect on Nigeria's imports and balance of payments. Imoisi (2012) examined the trends in Nigeria's balance of payment. The results indicate a significant relationship between balance of payments, exchange rate and interest rate. Agundu, Akani and Kpakol (2013) investigated exchange rate dynamics and balance of payments repositioning in Nigeria, using the multiple regression and log linear methods of data analysis covering the period 19862008. The findings showed that the current and the capital account of balance of payment have significant relationship with exchange rate, external reserves and external debt.

Umoru and Odjegba (2013) analysed the relationship between exchange rate misalignment and balance of payments (BOP) mal-adjustment in Nigeria using the vector error correction modeling technique and Granger Causality tests. Exchange rate misalignment has a positive impact on the Nigeria's balance of payments position. The Granger pairwise causality test result indicated a unidirectional causality running from exchange rate misalignment to balance of payments adjustment in Nigeria. Odili (2014) studied the effect of exchange rate and balance of payments 
using autoregressive distributed lag modeling in Nigeria. A statistically significant positive relationship exists between exchange rate and balance of payments in the long-run while the relationship is insignificant in the short run. Odili (2015) examined effects of exchange rate trends and volatility on imports in Nigeria. It was found that exchange rate trends had positive and significant effect on imports in the long-run.

\section{RESEARCH METHOD}

\section{Model Specification}

To examine the effect of exchange rate fluctuations on balance of payments in Nigeria, the model of Oladipupo and Onotaniyohuwo (2011) was adapted:

BOP $=\mathrm{f}($ EXRT,MS,ROUT,PRICE,INTR,INF, DOMC)

Where BOP is balance of payments, EXRT is exchange rate, MS is money supply, ROUT is real output, PRICE is price level, INTR is interest rate, INF is inflation rate and DOMC is nominal domestic credit. However, to capture the effects of exchange rate fluctuations on capital account component of balance of payments, we have the following model:
$\mathrm{CPA}=\beta 0+\beta 1 \log \mathrm{EXRT}+\beta 2 \log \mathrm{NDC}+\beta 3 \mathrm{INFR}$ $+\beta 4 \mathrm{INTR}+\beta 5 \mathrm{EXTR}+\mu$

$\mathrm{CPA}=$ Capital account component of balance of payments, $\beta 1, \beta 2, \beta 3, \beta 4, \beta 5$ are the parameters estimates while $\mu$ is the stochastic term. Akaike information criteria (AIC) and Schwarz information criterion (SIC) were used to determine the optimal lag length for the model.

Estimation Techniques

The study employed Johansen co-integration test, Error Correction Model (ECM) and Fully Modified Ordinary Least Square (FMOLS) to show the proportion of the variable effect on the capital account components of the balance of payments.

\section{RESULTS AND DISCUSSION}

Unit Root Test

Given the peculiar non-stationarity of most time series, the Augmented Dickey Fuller test is used to confirm the order of integration of the series.

Table 1.

Unit Root Test Result

\begin{tabular}{cccc}
\hline Variables & \multirow{2}{*}{ ADF } & Critical Value @ 5\% & Order of Integration(ADF) \\
\hline CPA & -4.686015 & -2.963972 & $\mathrm{I}(1)$ \\
\hline EXTR & -4.150587 & -2.957110 & $\mathrm{I}(1)$ \\
\hline INFL & -4.890132 & -2.963972 & $\mathrm{I}(1)$ \\
\hline INTR & -8.010686 & -2.963972 & $\mathrm{I}(1)$ \\
\hline LNDC & -6.045828 & -2.954021 & $\mathrm{I}(1)$ \\
\hline LEXR & -4.954605 & -2.963972 & $\mathrm{I}(1)$ \\
\hline
\end{tabular}

The results show that all of the series are stationary at first difference. The test statistics for current account, exchange rate, nominal domestic credit, interest rate, inflation rate and external reserve are all higher than the $5 \%$ critical value. Therefore, the null hypothesis of a unit root is rejected and they are all integrated of order one, I (1).
Co-Integration Test

The results of the co-integration tests in table 2 indicates the existence of one co-integrating equation in the model. The null hypothesis of no cointegration is rejected. 
Table 2.

Unrestricted Co-integration Tests

\begin{tabular}{ccccc}
\hline \multicolumn{5}{c}{ Unrestricted Co-integration Rank Test } \\
\hline Hypothesized & Trace & 0.05 & Max-Eigen & 0.05 \\
\hline No. of CE(s) & Statistic & Critical Value & Statistic & Critical Value \\
\hline None * & 111.0439 & 95.75366 & 35.42503 & 40.07757 \\
\hline At most 1 & 75.61889 & 69.81889 & 28.64444 & 33.87687 \\
\hline At most 2 & 46.97445 & 47.85613 & 27.85902 & 27.58434 \\
\hline At most 3 & 19.11543 & 29.79707 & 10.59879 & 21.13162 \\
\hline At most 4 & 8.516645 & 15.49471 & 6.132158 & 14.26460 \\
\hline At most 5 & 2.384488 & 3.841466 & 2.384488 & 3.841466 \\
\hline
\end{tabular}

Therefore, the variables converge in the long run, thereby depicting the existence of long run relationship among the capital account, ex- change rate, nominal domestic credit, interest rate, inflation rate and external reserve.

Error Correction Model

Table 3.

Parsimonious Error Correction Model Estimation

\begin{tabular}{lcccc}
\hline Variables & Coefficient & Standard Error & t-Statistics & p-Value \\
\hline $\mathrm{D}($ CPA(-1) & 0.284090 & 0.310601 & 0.914644 & 0.3748 \\
\hline $\mathrm{D}($ CPA(-2) & 1.064452 & 0.407615 & $2.611412^{* *}$ & 0.0196 \\
\hline $\mathrm{D}($ EXTR(-1) & $7.28 \mathrm{E}-05$ & 0.000646 & 0.112725 & 0.9117 \\
\hline $\mathrm{D}($ EXTR(-2) & 0.000710 & 0.000818 & 0.867192 & 0.3995 \\
\hline $\mathrm{D}($ LEXR(-1) & -84725.90 & 25232.89 & $-3.357757^{* * *}$ & 0.0043 \\
\hline $\mathrm{D}($ LEXR(-2) & -29943.23 & 20670.61 & -1.448590 & 0.1680 \\
\hline $\mathrm{D}$ (INFL(-1) & 365.9251 & 276.0100 & 1.325768 & 0.2048 \\
\hline $\mathrm{D}$ (INFR(-1) & 91.74485 & 373.6152 & 0.245560 & 0.8094 \\
\hline $\mathrm{D}($ LNDC(-1) & -16264.73 & 23630.33 & -0.688299 & 0.5018 \\
\hline $\mathrm{D}$ (LNDC(-2) & -32255.49 & 23417.07 & -1.377435 & 0.1886 \\
\hline $\mathrm{D}$ (INTR(-1) & 15594.97 & 4643.022 & $3.358798^{* * *}$ & 0.0043 \\
\hline $\mathrm{D}($ INTR(-2) & 4997.937 & 1715.766 & $2.912948^{* *}$ & 0.0107 \\
\hline $\mathrm{D}($ LEXR(-3) & -85199.92 & 20336.83 & $-4.189439^{* * *}$ & 0.0008 \\
\hline $\mathrm{C}$ & 0.015888 & 0.018456 & 0.860825 & 0.4029 \\
\hline ECT(-1) & 36453.51 & 13102.20 & $2.782244^{* *}$ & 0.0140 \\
\hline
\end{tabular}

$*^{* *},{ }^{* * *}$ imply significance at $10 \%, 5 \%$ and $1 \%$ level respectively

Table 3 shows the result of the parsimonious error correction model for the effect of exchange rate fluctuations on capital account using a parsimonious approach. This was set at lag 3 in accordance with lag selection to show the time lag it takes the capital account to converge back to equilibrium from disequilibrium. Based on the result, the error correction term has the correct sign (negative) meaning that about 70.90 percent of the errors being corrected yearly. It implies that the adjustment takes place relatively quickly. It also implies that when there is any disturbance, convergence to equilibrium is relatively high with 70.90 percent of adjustment occurring in the first year. Consequently, for an initial error of 1 percent, 70.90 percent of the error would be corrected in the first year. Bannerjee et al (1998) noted that a highly significant error correction term is further proof of a stable long-term relationship. Granger (1986) also noted that the existence of a significant 
error is evidence of causality in at least one direction.

In terms of the significance of the individual variables, one and two year lagged external reserve has positive effects on the capital account component of the balance of payments but it is statistically insignificant. In addition, one and two year lagged inflation rate has no effect on the capital account. Meanwhile, one and two year-lagged interest rates have significant positive effect on the capital account. Even though one and three year-lagged exchange rates have significant negative effect on capital account, it is insignificant for the two year lagged period. In addition, while one and two year lagged period of nominal domestic credit have statistically no effect on capital account, it has positive effect on the capital account component of the balance of payments for the three year lagged period. Furthermore, interest rates for one and two year lagged period have statistically no effect on capital account.

Table 4.

Long Run Coefficient of the Effect of Exchange Rate Fluctuations on Capital Account

Dependent Variable: CPA

\begin{tabular}{ccccc}
\hline \multicolumn{2}{l}{ Method: Fully Modified Ordinary Least Squares (FMOLS) } & \multicolumn{2}{l}{} \\
\hline Variable & Coefficient & Std. Error & t-Statistic & Prob. \\
\hline LEXR & 3793.387 & 3976.883 & 0.953859 & 0.3486 \\
\hline EXTR & -0.000626 & 0.000189 & $-3.307258^{* * *}$ & 0.0027 \\
\hline LNDC & 6265.805 & 4128.127 & 1.517832 & 0.1407 \\
\hline INFL & 0.717687 & 0.087198 & $8.230574^{* * *}$ & 0.0000 \\
\hline INTR & -5363.433 & 882.0220 & $-6.080838^{* * *}$ & 0.0000 \\
\hline C & -104692.2 & 100578.4 & -1.040901 & 0.3072 \\
\hline
\end{tabular}

*** Implies significance at $1 \%$

Table IV indicates the effect of exchange rate on capital account. Exchange rate, nominal domestic credit, inflation rate, interest rate and external reserve were regressed on capital account in order to determine the long run effect of the variables. The study also shows that exchange rate, nominal domestic credit and inflation rate have a positive effect on capital account while interest rate and external reserve have negative effect on the capital account. Obviously, the relationship between exchange rate, inflation rate and external reserve and the capital account does not conform to postulations in economic theory. However, the relationship between of nominal domestic credit, interest rate and the capital account are in tandem with theoretical expectation. In term of the significance of the individual variables, inflation rate, interest rate and external reserve are statistically significant at 1 percent while exchange rate and nominal domestic credit are not significant.

\section{CONCLUSION}

The result from the estimation of the model indicates that exchange rate and nominal domestic credit have positive association with the capital account in Nigeria. From the result, it shows that higher exchange rate improves the capital account. That is, as exchange rate depreciates (falls), the capital account does not improve. However, nominal domestic credit improves the capital account of balance of payment components. More so, the results also show that an increase in external reserves worsens the capital account of balance of payments, while an increase in inflation and interest rates does not worsen the capital accounts. From our findings, it has become imperative for the government to formulate policies towards curbing inflationary tendency, encourage market-determined interest rate that would stimulate production, consumption and investment in order to increase the country's external reserve thereby bringing about favorable 
balance of payments position. More so, the domestic credit rates have to be efficiently managed by the monetary authority to encourage and improve our balance of payments position and proper means of monitoring has to be introduced towards ensuring that available credit is being channeled to the right sector in order to improve the capital account.

\section{REFERENCES}

Agundu U.C, Akani W.H and Kpakol F.B (2013). Exchange Rate Dynamics and Balance of Payment Repositioning in Nigeria. European Journal of Business and Management 5(29), 84-91.

Alexander, S. (1952). Effects of Devaluation on a Trade Balance. IMF Staff Paper, April. International Monetary Fund, Washington DC.

Aliyu, S.U.R. (2009). Impact of Oil Price Shock and Exchange Rate Volatility on Economic Growth in Nigeria: An Empirical Investigation. Research Journal of International Studies, 11, 4-15.

Aliyu, S. U. R. (2007). Import - Export Demand Functions and Balance of Payments Stability in Nigeria: A Co-integration and Error Correction Modeling. Journal of Social and Management Sciences 20(2), 116-120.

Bannerjee A, Dolado J. and Mestre R. (1998). Error Correction Mechanism Test for Cointegration in the Single Equation Framework. Journal of Time Series Analysis 19, 267-283.

Frenkel, R. (2004). Real Exchange Rate and Employment in Argentina, Brazil, Chile and Mexico. Draft Paper Prepared for the G24 Conference, Mexico.

Imoisi, A. I. (2012). Trends in Nigeria Balance of Payments: An Empirical Analysis from 1970-2010. European Journal of Business and Management 4, 210-217.

Isard, P. (2007). Equilibrium Exchange Rates: Assessment Methodologies. IMF Working Paper WP/07/296, International Monetary Fund, Washington DC.

Kandil, M. (2009). Exchange Rate Fluctuations and Balance of Payments: Channels of In- teraction in Developing and Developed Countries. The Journal of Economic Integration 24(1), 151-174.

Obaseki, A. E. (2000). Balance of Payment: Issues and Crises. The Bullion 20(3), 130-131.

Odili, O. (2015). Effect of Exchange Rate Trend and Volatility on Imports in Nigeria: Implications for Macroeconomic Policy. International Journal of Economics, Commerce and Management 3(7),

Odili. O. (2014). Exchange Rate and Balance of Payment: An Autoregressive Distributed Lag (ARDL): An Econometric Investigation on Nigeria. IOSR Journal of Economics and Finance 4(6) 21-30.

Oladipupo, A. O. and Onotaniyohuwo, F. O. (2011). Impact of Exchange Rate on Balance of Payment in Nigeria. International Multidisciplinary Journal, Ethiopia, 5(4), 7388.

Onyinye, O. G. (2012). The Effect of Exchange Rate on the Nigerian Balance of Payments (19702010). Amorji-Nike: Caritus University.

Oyovwi, O.D. (2012). Exchange Rate Volatility and Imports in Nigeria. Academic Journal of Interdisciplinary Studies 1(2), 103-114.

Ozturk, L. and Acaravci, A. (2010). An Application of Thirlwall Law to the South African Economy: Evidence from ARDL bounds testing Approach.

Patricia, A. A., and Osi, C. I. (2010). Balance of Payments Adjustment in the West African Monetary Zone Experience. Journal of Economic and Monetary Integration 10, 100116.

Umoru, D. and Odjegba, O.P. (2013). Exchange Rate Misalignment and Balance of Payment Adjustment in Nigeria. European Scientific Journal 9 (13), 260-273. 